\title{
MICHELANGELO MERISI DA CARAVAGGIO AND MULTIMEDIA PRESENTATIONS - A MARRIAGE OF BEAUTY OF ART AND THE ART OF PRESENTATION
}

\author{
MICHELANGELO MERISI DA CARAVAGGIO I PREZENTACJE \\ MULTIMEDIALNE - MARIAŻ PIĘKNA SZTUKI I SZTUKI PREZENTACJI
}

\begin{abstract}
In this paper, the evolution of the style of Caravaggio had been traced and, focusing on the selected images it had been proved that the methods used by that eminent painter can successfully be applied during the creation of modern, effective multimedia presentations. The strength of Caravaggio was in its simplicity and mundane. For indicated formal measures may be included, inter alia: the elimination of tonally extended second plan and replace it with a dark, uniform background. Caravaggio calmed down composition painting almost monochromatic paintings, which emphasizes the foreground, as well as the keynote message. In the paper it was emphasized that exactly the same objectives should be guided in the creation of multimedia presentations, extracted from unnecessary embellishments that irrupt to the fore dispersing attention. Based on the analysis of selected paintings, in the article, review of procedures associated with the colors of multimedia presentations, extremely important in creating multimedia presentations and highlighting media had been proposed. Several theories related to the psychology of color had been also presented, and also sought to answer the question of why we should not trust psychologists boundlessly.
\end{abstract}

Keywords: art, background, Caravaggio, color, multimedia, paintings, presentations

\section{One who knocked off saints from the heavens}

Bożena Fabiani asked in her book [1]: ,...I have to see Rome”, what is extraordinary in Caravaggio's paintings that makes him so popular among researchers and art lovers. I think, the power of outstanding painter is, primarily, in simplicity and mundanity - in this simplicity that pushed him to avoid searching a Renaissance idealization or beauty in religious paintings. His realism escalated with every drawing and religious scenes were almost secular. When the other artists pretended that they see the afterlife almost as medieval mystics - after all the paintings are full of levitating saints surrounded by clouds or supported on the shoulders of angels that during the break in flying they receive stigmata Caravaggio cut this type of emotions. As Fabiani stresses, saints who have been recently elevated above the ground by Rafael and Titian, he knocked from highlands, clouds and

\footnotetext{
${ }^{1}$ Faculty of Environmental Engineering, Warsaw University of Technology, ul. Nowowiejska 20, 00-653, Warsaw, Poland, phone +48 2223454 17, email: miroslaw.szydlowski@is.pw.edu.pl
} 
heavens. He told them to avoid exaltation, tread firmly on the ground and die there - even during the holy martyrdom, the heaven on Caravaggio's paintings is silent. We will find angels only then when principal wished for it. Even then they are physical and sensual and have very little of angelicism in themselves (vide image Rest during an escape to Egypt). Mundanity, ordinariness and commonness prevail.

Saint Mary Magdalene is lost in reverie and she is similarly as other saints on the visible and material side that the artist knows well and is able to splendidly reflect. They are ordinary people who treading barefoot, dirty, covered with dust and tired. They have features of common peasants! Mother Mary is stripped from all external majesty by the artist who - having for nothing assignments of the Council of Trent ${ }^{2}$ - gave her a face of Lena, woman commonly known in Rome, known as a model and a neighbor from Piazza Navona. It is she, who is portrayed on the painting of Mother Mary with a child and Saint Ann. She has a low-cut and tucked dress that is ligated at the hip as a common laundress. She leads naked Jesus. Next to her, we see Saint Ann - ugly, old simpleton who is very skinny, dried on a chip (her features are similar to Mother Lena). The darkness of history hides the secrets why Caravaggio did not stand in front of inquisition tribunal, especially that he completely did not worry about an iconographic holy tradition according to which Madonna had blue coat. Please, look at Loretto Madonna - the painter finding that the blue color is a poison of painting imposed on Mother Mary arms (again of Lena's face) a worn dress. Let's look on The sleep of Mother Mary - here poor woman with naked feet and swollen belly is dying on the bed. She is surrounded by a group of aging simpletons who wipe their eyes. Where is decorum and dignity of the Queen of the World and seriousness of the holy image? Where are the angels choirs and divine intervention? The trend of Caravaggio was the one proposed by Saint Phillip, trend of plebeian's piety. Fabiani presumed that he was looking for the truth stubbornly and obsessively [2]. That means he asked a question how did it really happen? How did it have to look? He did not care how the scene has been shown by his predecessor for centuries. He turned from the iconographic tradition, hated fabrications and imitation. He did not like mythology and recognized only life itself, cared for true event and how to show it through what props and realities. Giotto, first master of narrative, discovered how to paint the story through gestures and webs of looks. Caravaggio did not behave differently when he was painting the drawing from which the previous situation can be read as well as the one that is coming [2].

Caravaggio, far from glorifying beauty, did not make his models prettier and he did not look for especially beautiful ones. He painted barefoot, dirty and casual and repulsive. What is even worse he was fond of setting the characters on the foreground from the back release to the spectator. It showed dirty feet to everyone who wanted to kneel in front of Loretto Madonna or Crucifixion of Saint Peter. Next to the painting that shows punishment of the first Pope in Santa Maria Del Popolo, hangs Assumption of the Virgin by Carracci (Fig. 1). As for this artist it is full of pathos, swelling of and glow. It is a work of strange and artificial dynamic composition.

When we track evolution of Caravaggio style we will notice that besides perfect deepen the shadows and elimination of expanded in tones second plan and replacing it by the dark, homogeneous background. Composition became calm and the painting almost monochrome with depth psychic of the character (Beheading of Saint John Baptist, The Resurrection of

\footnotetext{
${ }^{2}$ Nihil profanum nihilque inhonestum-cleanse form the secularism and indecency the sacrum art
} 
Lazarus) [3]. I came across an opinion Galiński, that the goal of this solution was to strengthen clarity of the main motive [4]. Please, compare two paintings of the same title Supper in Emaus painted in 1601 (National Gallery, London) and 1606 (Pinacoteca di Brera, Milan). Five years of difference - not much especially if comes to art, but the works are completely different. The second one is opening new, mature period in Caravaggio's life. Christ is shrouded in darkness and at the same time dazzling simplicity, balance and casualness. The spectator is concentrated on the most important. His attention is not disturbed by unimportant details that take his attention away from the main message. In painting from 1601 Christ is nothing almost like Bacchus who lean on the richly prepared table. I will repeat. There is five years of difference between the paintings. Five years during which the painter started his journey going with the difficulty through next topics for the drawings dedicated for the church. The unfaithful painter together with the characters of the paintings, unfaithful Thomas and unfaithful Matthew were breaking their heads over the mystery of God [2].
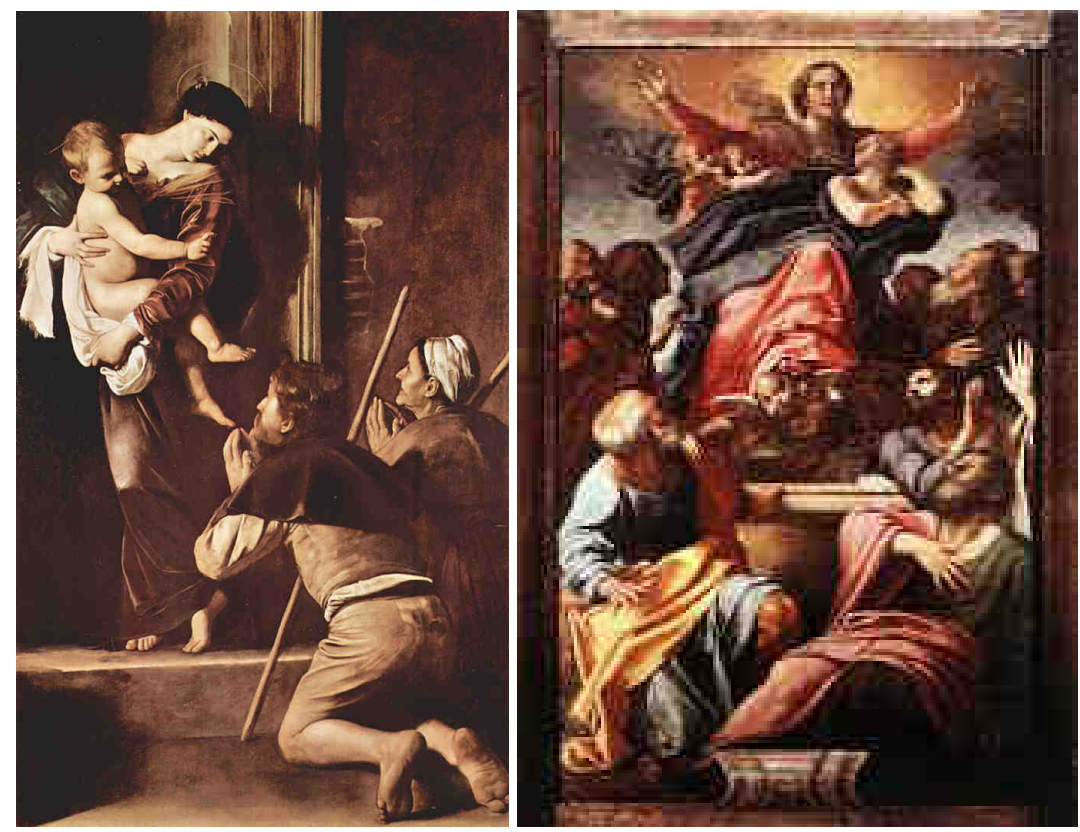

Fig 1. Two Virgins - Loretto Madonna by Caravaggio and Assumption of the Virgin by Carracci

\section{The light and the shadows}

Fabiani in her essay „Bully Caravaggio” writes that the painter used some formal sources that strengthen significance of the paintings [2]. Primarily he brought different light. First paintings were light later his paintings are getting darker. The light is not equally distributed according to the rules of the Renaissance generation. Caravaggio needs this light that will reveal something making the action, busy light bringing the things and people from the dark. The lab walls he covers with black paint. He liquidates a plain window and puts it 
at the top. He receives the beam and he puts it on the canvas. He understands that revelation can happen in one minute and he is trying to find this minute on every of his canvases. He is not distracted. He paints only a second of an event subordinating everything to it - the gestures, looks, and attributes. His paintings are overtalked and overload. They have everything what is necessary. The paintings are beautiful. They attract the eye. They are not boring, they fascinate and inspire. Furthermore, looking at the arts of Gentileshi, Manfredi, Caracciolo, de Boulogne, van Baburen or Georges de La Tour - "caravaggionism" in a simple form! Let's stop at the last painting. In essay „Georges de La Tour - in a candle light" Bożena Fabiani wrote, that we can read that the painter stayed under a strong influence of Caravaggio, what was expressed primarily by looking for the light effects: darkness, deep shadow, light contrasts. In religious topics this influence was visible particularly in investigating the mystery, perception of the supernatural by the simpleton and transferring them directly without any complications [2]. He was called the painter of peasants because the action of his paintings he put among ordinary people, poverty and everyday life. His works show calmness and are not overloaded and overtalked. His characters are calm peasants as the first peasants and as he was himself first. De La Tour was fond of nocturnes, candlelight that smoothed the faces and eases colors of the clothes. Reverie and silence are the ones that make the sacrum? Do you need anything else? It has to be added that Caravaggio's paintings besides that they fascinate they also transmit great peoples' emotions: amazement, anxiety, fear, delight, despair... . At the same time the works are full of hidden dramaturgy that is shown in excellent way on the paintings that were painted for the church chapels. An unique language of the eyes and gestures and the moment that is stopped by the movie frame. I have to quote the words of Bożena Fabiani who noticed something else. Caravaggio builds his painting in a way that the spectator may participate in the event that is shown on the painting. The group of people painted on the work leaves empty spaces from the spectator side. The painting is open from our side. The best it is shown on Entombment where the pyramid of people stands behind the grave and the spectator see the front of the grave. If we would like to seat next to the sitting in the Supper in Emaus, no problem, the painter left for us empty sits by the table. Please, look at the Sacrifice of Isaac Caravaggio grouped people and the animal in a way that it looks like modern camera's shoot. Everything can be caught by the picture. Kind of like a classic example of condensation paint where the artist resigns from the full narration and we do not know where the event takes place. However, the intriguing composition is very memorable. I mentioned before Annibale Carracci, the author of Assumption of the Virgin; I think that it is worth to remind the reaction of his cousin Lodovic when he saw one of the Caravaggio's paintings. So the founder of the Bologna painting school ,Simply was petrified when he saw that there is nothing besides huge light contrast and shadows, no excuses for what is proper, no charm or understanding, a real crash of the good drawing." [1]. The time showed that Caravaggio not only bury the good drawing but also and despite of that prophets have generally harder in life he was a real pioneer. That is him who restored for the human his corporeality and at the same time plunged him in the darkness [3]. He dared his followers to start looking for light effects and shadows game and the light of candlelight and the torch light. 


\section{Backgrounds colors as carriers of emotions}

What does it have in common with Power Point? Against guise, not a few. Anna Marciniak noticed in her essay that the color is important during multimedia presentation creations and featured in transmission [5]. The colors should not be used in a huge amount including white and black limiting them to three colors on one screen in graphic and text (of course avoiding pictures). The author advices that information important for the transmission should be marked with warm colors: red, orange, yellow, because in the nature they are warning colors. Moreover, they give effect of convexity and zoom on the screen. The content that is less important may be presented in cold colors. In order to pay attention on particular information we may use dissonances and color inversions (reverse of colors). The background cannot be interrupted with elements that are in it. Therefore, the background as pictures should be very carefully chosen and slides should be neatly chosen as well both from the color side as from the ornament of the scheme [5].

Specialists of color psychology turn our attention to show that blue color is mostly chosen for multimedia presentations [6]. Tests proved that blue color makes our breath and pulse slower. It is calming and preservative. It found its popularity in business presentations and trainers presentations. Precisely the dark blue background and light letters (the set is associated with professionalism) in excellent way they are the best for serious, corporative presentations and light blue in the ones that are designed to making an effect of peace, reliability, partnership, trust and [7], in one word: warmer feelings on the speaker - audience line.

Green color stimulates interaction between speaker and listeners. Blue color interacts on positive emotions. It is often used by lecturers, trainers and all who would like the discussion. According to mentioned psychologists [7], the color is excellent for presentations that treats about ecological and environmental issues. In my opinion using green color in this context is obvious and trivial. Red color is one of the strongest colors in the color palette. If comes to affecting the emotions - also the negative ones so please be careful using it. This color is excellent as a carrier that stresses passion. Please, remember that it is also warning color that goes well with the slides in which we want to show threat or dangerous situation. Interesting and desired effect we will achieve when we will be talking about competition displaying slides on the red background, but as I mentioned it is not worth to exaggerate. Often I read that the presentations on the red background stimulate to take action especially when we want to show to the team that the deadline to deliver the project was the day before yesterday. Unfortunately, the willingness to act is connected only with the desire to come to the speaker and pull the cable from the projector. Purple or violet are associated with nimbus of the power and wealth. What is interesting violet means also wisdom and spirituality. This color infrequent in nature is perceived as something unusual and artificial. The feminine color most often is used in calm emotional and spiritual presentations. Contrary to appearances, yellow color may give feelings of frustration and anger. In spite of that it is a happy color and favors good mood. It has been proven that little children cry more often in yellow rooms [6]. It is color that is the most transparent and at the same time color that strongly point out. It may be used - in a small scale - for marking out or exposing some content, key words but it is avoid in the backgrounds. If there is a need the most often the sober shades as gold or orange are chosen. Orange is a color that is associated with light, sunny day, sweetness of honey, joy and positive emotions [7]. Very 
popular trick is also applying a delicate texture for the background or putting on picture with a transparency - then it makes the yellow effect more mild.

Black color is very often skipped in multimedia presentations, because of its neutral character it is excellent for financial presentations. Black color is associated with the finality. Moreover, it is good as a transition color - disappearance, fading to the black color gives a strong effect for the listeners to pay their attention.

White color similarly as black is a calm and neutral color for presentations. Unfortunately, white is often not appreciated as a color. Transition to the white color is indicating a new opening, beginning, cleanness and innocence. This color is ideal if we want to pay attention on the message, information from the slides in contrary to creation of the brand image. It symbolizes openness, it encourages and not overwhelms. It creates an open space impression. Psychologists [6] say that it can be perceived also as a ,cheap", boring because it is a default color in Power Point presentations. Moreover, it can make eyes tired.

Grey is often perceived as a negative color that testifies lack of engagement "passing by" the presentation. It may be a sign of independence, but as I mentioned the risk of label „,boring and not engaged” is huge here. On the other hand, colors as grey or silver are slowly in favor as less strict and severe, sterile and sharper than white [6]. In one word, in light grey background with the dark text or dark grey background with light text there is a great potential. Based on psychologists' research there might be a combination of colors together with the emotions that they play (Table 1).

Background colors and emotions caused by them $[6,8]$

Table 1

\begin{tabular}{|c|c|}
\hline Color & Emotions and connotations associated with color \\
\hline Black & sadness, seriousness, finality, formality \\
\hline Brown & earth, open space, simplicity \\
\hline Blue & peace, silence, trust, security, professionalism \\
\hline Violet & power, knowledge, mystery, spirituality \\
\hline Green & nature, environment, health, reptiles, insects \\
\hline Grey & conservatism, practicality, reliability, safety, stability \\
\hline Red & passion, intensity, excitement, warmth, love, aggression \\
\hline Orange & warmth, expansiveness, flamboyance \\
\hline Yellow & optimism, happiness, idealism, unreality \\
\hline White & purity, sterility, respect, simplicity \\
\hline
\end{tabular}

It is worth to pay attention to one more aspect - contrast. Backgrounds and text colors have to be contrasted against each other to make an impression of text convexity. In order to check if chosen by us colors are compatible it is worth to take contrast calculator that is put on the website: http://www.thinkoutsidetheslide.com/color-contrast-calculator/

Independently from the achieved score in the above test, some colors do not match with each other - they make the reading harder. There are [8]:

- $\quad$ red and green - apart from that healthy people have problem with this set of colors on slides, people that suffer from daltonism do not recognize the tones;

- $\quad$ orange and blue - next set makes discomfort in the receiver. The text seems to shake and vibrate and is hard to read; 
- $\quad$ red and blue - these colors will not pass the above test. Put next to each other they are not of much contrast. Worse, the combination seems less of contrast if it will be displayed on the screen.

So what color pairs look the best on the screen? One of the authors recommend the following set [8]:

- $\quad$ dark background with light text:

background: dark blue (hue "navy") or dark purple;

text: white or yellow;

colors of distinction: green, orange, light blue;

- bright background with dark text:

background: dark beige;

text: dark blue, black, dark purple;

colors of distinction: dark green, burgundy.

\section{Why we should not trust psychologists boundlessly?}

Giving the voice to psychologists I will allow myself to quote the words of those who warn before the contemporary, sometimes fanatic and fideic faith in this field. William Kirk Kilpatrick, the author of Psychological seduction [9], stated that if someone wants to discover new worlds it is the best to look for them outside of psychology. It gives an illusion of depth. The same illusion can be put on the opposite sides mirrors. It would like to be said following Lec that the mud sometimes gives you impression of depth. I will use another quote of psychology professor Tomasz Witkowski: Psychology is primarily the science of scientific method - it does not know anything for sure and it should not decide about anything. It may only suggest in what ways it will be the easiest to achieve the goal, but will not tell us to what aims to aim for [10]. In one word, the below paragraphs about colors may have its scientific proof and we could find many articles to support that and in which there is a discouragement from the faith for all who dared to use the background that is not enough to be pigeonhole. The question remains what do we loose? If the answer is yes then is this a goal and sense of our presentation and reaching the recipient? Of course we can change backgrounds in order to move emotions. We can dazzle of red to make the listener nervous. We can use the green and give him hope. We can also enchant the audience with a deep purple in order to show our spirituality and power... . We can do everything, but the question is what stays? What will stay in the heads of the listeners after they will leave the room? Emotions? Great, we wanted that. What about knowledge? What about the values we wanted to show?

When the slides are overwhelmed, the spectators try to understand instead of paying attention on the speaker; when they will pay attention to the speaker then they will look at the slide and will synchronize the two sources of information. It is an effect of not paying attention that brings cognitive overload and reduces effectiveness to lear. People better understand the multimedia presentation if they do not need to share attention between numerous sources of information and link them together [11]. We can't assume that the listeners have such a great working memory that they will read the whole material as a hard copy document and additionally will listen to the speech. Slides filled with text do not have an effective possibility to transfer the information in visual channel in synchronization of verbal channel. Atkinson wrote that the research shows that people better learn the words 
and pictures than the goals. It refers to the situation where pictures are presented in order to illustrate the words and not as a decoration [11]. Logo is an ornament that is permanently used for presentations and comes back as a mantra slide after slide. I have nothing against to put it on the opening and closing slides, but repeating it every time is to the slides we put additional, not necessary information that are not connected with a concrete topic mentioned in the title. Let's look on Caravaggio's paintings, particularly on the background. Do we have something redundant and oversized here? No - the blackness is a usual beam of light. The beam that reflects the most important person on the canvas. The most important detail. Nothing takes our attention. We can concentrate on the details and transfer on that what the artist wanted to show us. Let's recall The kiss of Judas (Fig. 2) - the light that comes from a lamp handled by Caravaggio reflects the face of Christ in pain. We see the face. The soldiers painted by chiaroscuro technique hide in the shadow not only shadows dancing in the armor that show some details of the kit. Let's look at David with the head of Goliath - it is David reflected diagonally.
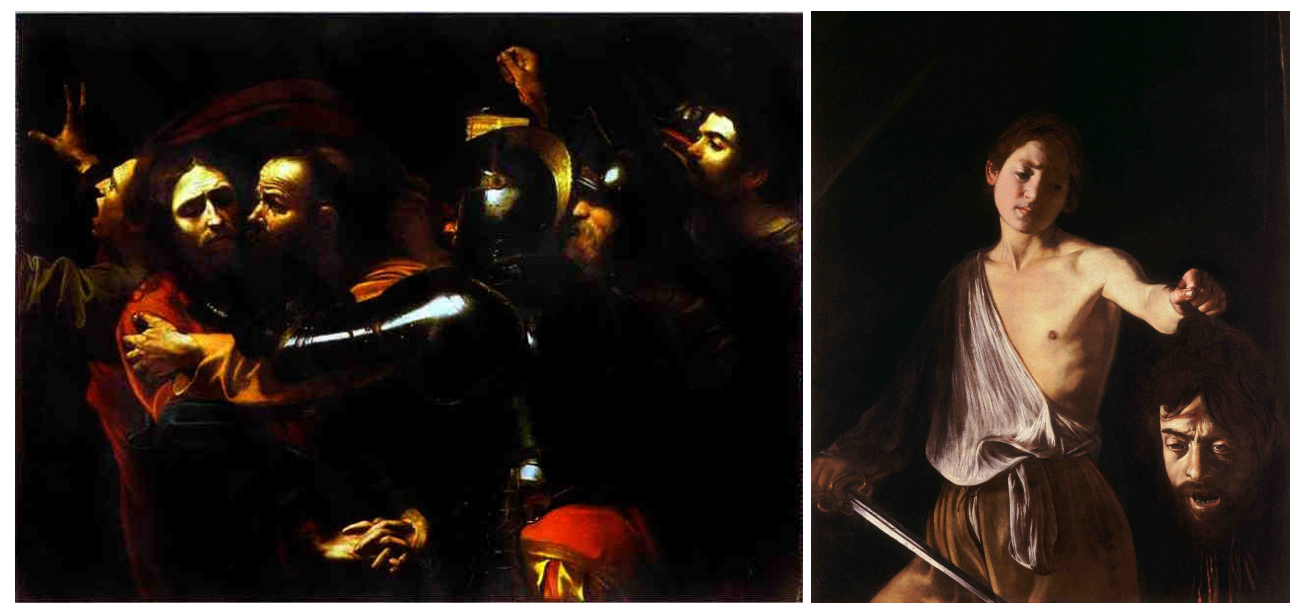

Fig. 2. The kiss of Judas and David with the head of Goliath

The painter exposes David's left arm and the head of the defeated (again we see the face of Caravaggio, possessed by the death through decapitation). The lack of details on the background even if we would like to put Israelities crowds there that cheer to the victory over The Philistines eventually king Saul who is thoughtful how to mock from the promise of giving his own daughter to the winner. On the picture we see only the youngest son of Jesse - yesterday a shepherd tomorrow a king. He is sad and thoughtful far from happiness. $\mathrm{He}$ is starring in the Goliath's-Caravaggio's head, that express the failure. And that is probably why this picture strongly influences on the next generation of recipients.

What is the most important suffering, fear and sadness and two of people's drama that soon will be the drama of the whole nations. Let's not to beautify the background with the nice (according to us) landscapes. Let's the message speaks. If it is deliberated then it will not need the decoration. If it is not then any of the ornaments will rescue it (Fig. 3). Nicholas Oulton in his important work "Killer presentations" writes that spending time on 
worrying about the choice of the picture on the background instead of spending it on worrying about the content of the presentation, it is almost like a crime [12].
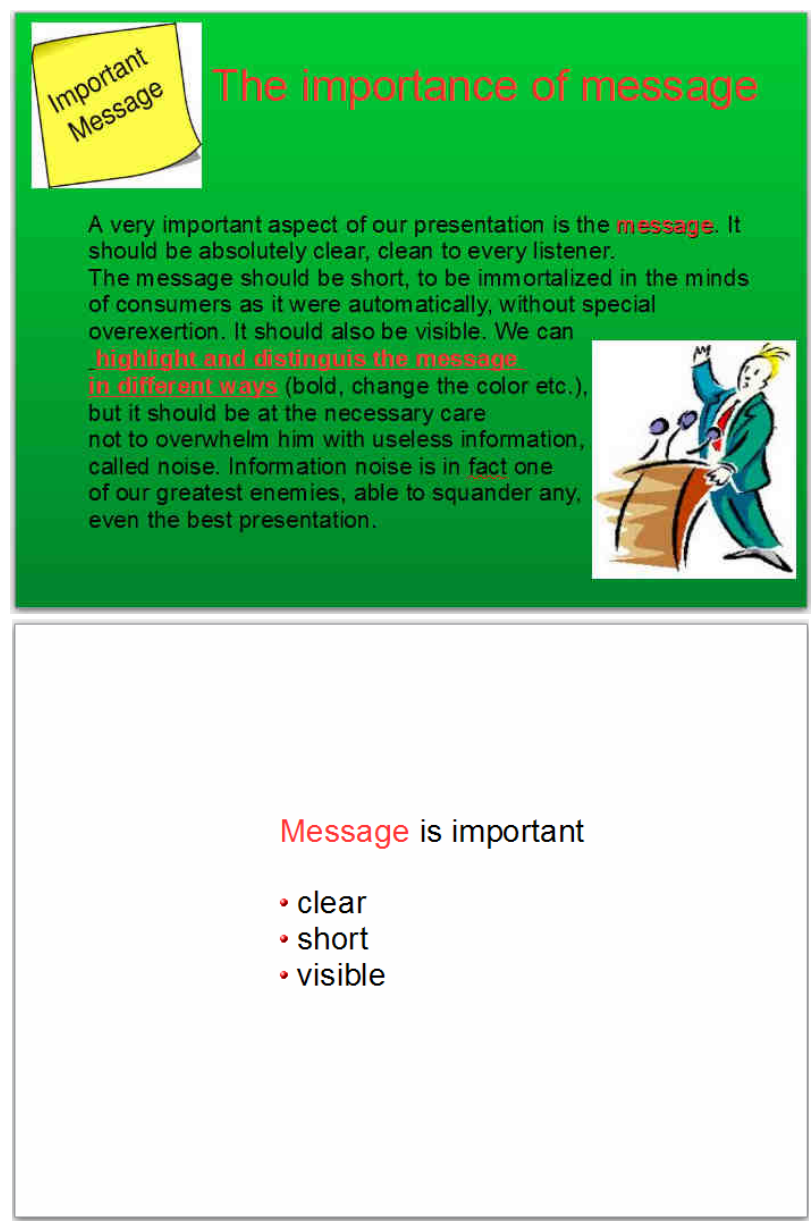

Fig. 3. Overloaded (above) and clean (below) slide. The above one is full of text, which overwhelms the main idea. There are a "deadly" set of colors red-green, unnecessary underline and irritating cliparts (according to N. Oulton, it is an abbreviation of: Crass Little Inserted Pictures Always Rubbish and Trite [12])

C. Atkinson suggests that the important slides should be distinguished by different background - when the dominating presentation background is for example white, the slides might be on the dark grey background. It can give the listeners a signal that these are the most important slides of the presentation [11]. The change will make the audience to pay attention what is significant, because after 15 minutes less than $35 \%$ of the public is not interested in what we say [13]. You should be very careful with this solution. Especially when we have the tendency to recognize that everything is significantly important - in this case the white background will be aberration for the all present greyness. 
Very strong effect is in making the screen black ("B" button on the keyboard). Visual elements are display on the screen and may enchant, but when we break the miracle by making it dark in the same moment we will transfer the attention on ourselves and on the presentation content. Sometimes we have a situation that the full attention is concentrated on the speaker. It is especially when we notice that the listeners instead of listening look at the slides. Pressing the "B" button makes a strong dramatic effect which all eyes in one second are on the presenter. If we have a black background of our slides then the similar effect we will have pressing "W" - then the screen will become white. Atkinson says you have to fully agree that the choice of a plain style may be a good strategy [11]. If all people use the same elegant, detailed and mistakeless style then all presentations will look the same. When we choose something simple that is in contrast with a norm, we may break visual boredom and make a lasting impression.

Let's go back to the Caravaggio's genius. I will allow myself to remind that he almost invited the recipient to come to his paintings, to sit next to Matthew and listen in his words after which the custom official from Cafarnaum, man who represents the profession as controversial as prostitutes, unfaithful and pagans just stood up and left with $\operatorname{Him}(\mathrm{Mt}, 9,9)$. There is a rule that should be honored during the proclamation of the presentation. As a popular Confucious motto say: "tell me and I will forget; show me and I will remember; engage me and you will wake up my desire". Atkinson that I mentioned already many times says that ,the basic rule number 1 is: enter the screen - the audience has to delve in the presentation as in a metaphor [11]. It should be taken and enchanted. We can do it by going in to the screen. Do not stand next to the screen and treat it only as a visual support. Let's stand in front of the big screen and make hybride transfer source and our presence will be engaging. It gives a sound effect that stresses all as a whole. Thanks to us the presentation is set in reality and the voice drives the whole process and information [11]. As it is seen the sources used by Caravaggio are universal and they are also useful in multimedia presentations. What impressed us, and shocked admirers of the XVII century art may pleased us who use electronics in XXI century. Please, pay your attention to the two of the first chapters of this text while making your presentation. You will be convinced that the chapters treat also about the Power Point. They say about what you need to know while preparing the presentation that you should concentrate on the detail and transfer and avoid the ornaments. In one word during all the centuries we forgot about the colors of presentations.

Gustaw Herling-Grudziński wrote about Caravaggio's works that the light and the shadow express invisible world [14]. I will repeat: light and shadow nothing more. I wish you that your presentations will be based on this motive where the light is the transfer that you want to attract the audience and the shadow is the background where all the ornaments are hidden.

\section{References}

[1] Fabiani B. ...Muszę i Rzym zobaczyć. Warszawa: Oficyna Wydawnicza "Vocatio"; 1999.

[2] Fabiani B. Dalsze gawędy o sztuce. XVII wiek. Warszawa: Polskie Wydawnictwo Naukowe; 2013.

[3] http://www.mojeobrazy.com.pl/malarz.php?id=95 (access: 09.06.2014).

[4] Galiński PT. Caravaggio i caravaggioniści. Source: http://pawtadgal.blogspot.com/2014/01/uzupenienia-iicaravaggio-i.html (access: 09.06.2014).

[5] Marciniak A. Sztuka tworzenia prezentacji multimedialnych. Source: http://www.marciniak.edu.pl/ resources/articles/Sztuka_tworzenia_prezentacji_multimedialnych.pdf (access: 25.06.2014). 
[6] http://www.presentationteam.com/presentation-tips/powerpoint-tips/psychology-of-color-in-powerpointpresentations (access: 26.06.2014).

[7] http://www.presentation-process.com/colors-in-powerpoint.html\#axzz35eKHHdGZ (access: 26.06.2014).

[8] http://www.thinkoutsidetheslide.com/choosing-colors-for-your-presentation-slides/ (access: 26.06.2014).

[9] Kirkpatrick W. Psychological Seduction. Nashville: Thomas Nelson Inc.; 1983.

[10] Giedrys G. Pełnia obecności. Wysokie Obcasy. 2014; 90-92.

[11] Atkinson C. Beyond Bullet Points. Gliwice: Helion; 2011.

[12] Oulton N. Killer Presentations. London: How to Books Ltd; 2007.

[13] Szyłak-Szydłowski M. Sztuka prezentacji, czyli zastosowanie multimediów w dydaktyce. Chem Dydakt Ekol Metrol. 2010;15(2):197-199. http://tchie.uni.opole.pl/freeCDEM/CDEM_15\%282\%29/ CDEM_15\%282\%29.pdf

[14] Herling-Grudziński G. Sześć medalionów i srebrna szkatułka. Warszawa: Czytelnik; 1994.

\title{
MICHEL ANGELO MERISI DA CARAVAGGIO I PREZENTACJE MULTIMEDIALNE - MARIAŻ PIĘKNA SZTUKI I SZTUKI PREZENTACJI
}

\author{
Wydział Inżynierii Środowiska, Politechnika Warszawska
}

\begin{abstract}
Abstrakt: W artykule, prześledziwszy ewolucję stylu Caravaggio i skupiwszy się na wybranych obrazach, dowiedziono, że metody stosowane przez tego wybitnego malarza z powodzeniem mogą zostać wykorzystane podczas tworzenia współczesnych, efektywnych prezentacji multimedialnych. Napisano, że siła tego wybitnego malarza tkwiła w prostocie i przyziemności. Do wspomnianych środków formalnych zaliczone mogą być między innymi: eliminacja rozbudowanego tonalnie drugiego planu i zastąpienie go ciemnym, jednolitym tłem. Caravaggio „uspokoił” kompozycję, malując niemal monochromatyczne obrazy uwypuklające plan pierwszy, przekaz i myśl przewodnią. W artykule podkreślono, że dokładnie te same cele przyświecać powinny w tworzeniu prezentacji multimedialnych, wyekstrahowanych z ozdobników wdzierających się niepotrzebnie na pierwszy plan, rozpraszając uwagę odbiorcy. Na podstawie analizy wybranych obrazów zaproponowano przegląd zabiegów związanych $\mathrm{z}$ kolorystyką $\mathrm{w}$ prezentacjach multimedialnych, niezmiernie istotną przy tworzeniu prezentacji multimedialnych i uwypuklaniu przekazu. Przedstawiono tu kilka teorii związanych z psychologią barw, a zarazem starano się odpowiedzieć na pytanie, dlaczego nie należy bezgranicznie ufać psychologom.
\end{abstract}

Słowa kluczowe: barwa, Caravaggio, multimedia, obrazy, prezentacje, sztuka, tło 